How to cite: Grigorescu, I., Micu, D., Dumitrașcu, M., Mitrică, B., Mocanu, I., Șerban, P., Dumitrică, C., Havriş, L., Kucsicsa, Gh. (2019) Renewable Energy Sources in Romania: Progress and Perspectives Towards the EU Targets. 2019 "Air and Water - Components of the Environment" Conference Proceedings, Cluj-Napoca, Romania, p. 9-18, DOI: 10.24193/AWC2019 02 .

\title{
RENEWABLE ENERGY SOURCES IN ROMANIA: PROGRESS AND PERSPECTIVES TOWARDS THE EU TARGETS
}

\author{
Ines GRIGORESCU $U^{\natural}$, Dana MICU $U^{1}$, Monica DUMITRAȘCU ${ }^{1}$, Bianca

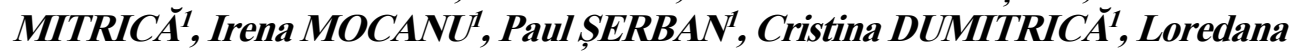 \\ HAVRIS, Gheorghe KUCSICSA ${ }^{1}$
}

DOI: 10.24193/AWC2019_02

\begin{abstract}
The renewable energy is the solution to the global energy issue, generated by the increased energy consumption needs under the continuous population growth and economic development. Romania has reached the 2020 target to increase the share of renewable energy sources (RES) in gross final energy consumption to $24 \%$, as set in the energy strategy for 20072020 (updated for 2011-2020). However, in view of reaching the new target set for 2030 (32\%), a number of measures are envisaged. The authors investigated the dynamics in the share of RES and electricity production over 2014-2017 in relation to the EU 2020 targets, and reviewed the main strategic EU and national documents over the 2007-2020 financial period. The final aim was to identify the investment priorities and measures supporting extended RES use and increase of energy efficiency towards the achievement of the next 2030 EU target in Romania.
\end{abstract}

Keywords: renewable energy sources, energy efficiency, EU targets, Romania.

\section{INTRODUCTION}

The increasing energy consumption needs under the continuous population growth and economic development demands for increased living standards, thus putting greater pressure on natural resources. United Nation General Assembly declared the decade 2014 2024 as the "Decade of Sustainable Energy for All" (UN, 2014), and the extended use of renewable energy sources (RES) is recognized as a reliable solution to support this desideratum. RES share in the gross final energy consumption is expected to increase substantially across the European Union from $8.1 \%$ in 2005 to $20.6 \%$ in 2020 (Scarlat et al., 2015; Radovanović et al., 2017), as set in 2009/28/EC Directive on the promotion of the use of energy from renewable sources.

The first EU Green Paper (2000) has been devoted entirely to energy security, addressing the need to ensure a long-term well-being of [EU] citizens, the proper functioning of the economy and the availability of energy products on the market at an affordable price for its consumers. The most recent Green Paper (2013) integrated different EU policy objectives (e.g. reduction of greenhouse emissions, security in energy supply,

\footnotetext{
${ }^{1}$ Romanian Academy, Institute of Geography, inesgrigorescu@yahoo.com
} 
cost effectiveness and resource efficiency), foreseen to be delivered by three main targets: reduction of green house gases (GHG) emissions, renewable energy and energy savings. This framework took into account the long-term perspectives envisaged in the EU Commission Roadmap supporting the transition towards a low-carbon economy by 2050, the Energy Roadmap 2050 and the Transport White Paper. These documents which have been developed in line with the climate change mitigation objective of reducing GHG emissions with 80 to $95 \%$ by 2050 relative to the 1990 level and with the internationally agreed target to limit atmospheric warming to below $2^{\circ} \mathrm{C}$.

Currently, the main EU documents addressing energy and climate policies are the Europe 2020 Strategy and the recently ratified Paris Agreement (Radovanović et al., 2017). The Europe 2020 strategy targets on climate change and energy (the "20-20-20 targets"), seek to reduce GHG emissions and increase energy efficiency (European Commission, 2010). After joining the EU, Romania faced significant changes in the alignment energy policy and legislation and promotion of renewable energy (Colesca and Ciocoiu, 2013; Zamfir at al., 2016), but also became attractive for investments.

The paper is seeking to evaluate the context and progress towards meeting the EU targets related to RES and energy efficiency and the perspectives for a further RES use in Romania. The research objectives are: (1) to outline the structure of energy sources mix and RES potential; (2) to analyze the dynamics of RES share and electricity production over 2014-2017 period in relation to the EU 2020 targets and (3) to identify the investment priorities and measures supporting extended RES use and increase of energy efficiency towards the achievement of the EU 2030 targets.

\section{DATA AND METHODS}

Several key statistical RES-related indicators of energy production and consumption in Romania have been analyzed, and the main strategic EU/national documents and Operational Programmes (OPs) for the 2007-2020 financial period have been reviewed. The statistical data were provided by the National Institute of Statistics (Tempo-Online), the National Regulatory Authority for Energy (ANRE) and Transelectrica in order to highlight the dynamics and the differences in the use of different conventional and RES.

\section{RESULTS AND DISCUSSIONS}

\subsection{Energy sources mix and RES potential}

Romania has a diversified mix of energy sources, mostly based on indigenous resources. In 2016, the structure of electricity production included: $29 \%$ hydro, $25 \%$ coal (mainly lignite), 18\% nuclear, 15\% natural gas, 10\% wind, 2\% photovoltaic and 1\% biomass (Fig. 1). Wind energy was included in the energy circuit since 2010 and solar since 2012. Thus, there was a transition from a dual energy production pattern in the early 90s (thermoelectric and hydroelectric) to a triple pattern between 1996 and 2006 (thermo, hydro- and nuclear) and ultimately a multiple pattern by adding RES (Fig. 2). 
The coal and natural gas thermoelectric capacities represented approximately $40 \%$ of the gross available power in 2015. In addition, Romania falls among the 14 EU member states that use nuclear energy. Hydroelectric power plants are a key component of RES due to the energy stored in water reservoirs with an essential role in balancing the energy market.

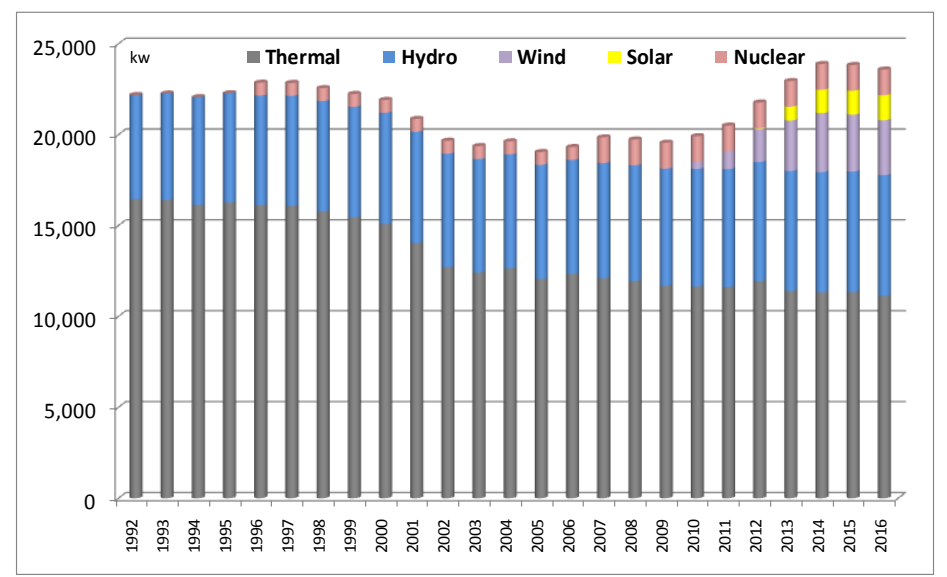

Fig. 1. Structure of installed power by electric generating sets (1996-2016).

Given that most the hydroelectric power plants are dated, Hidroelectrica is planning to invest over $€ 800$ million by 2020 for the modernization and upgrading in order to increase efficiency (Romanian Energy Strategy 2016-2030, 2016).

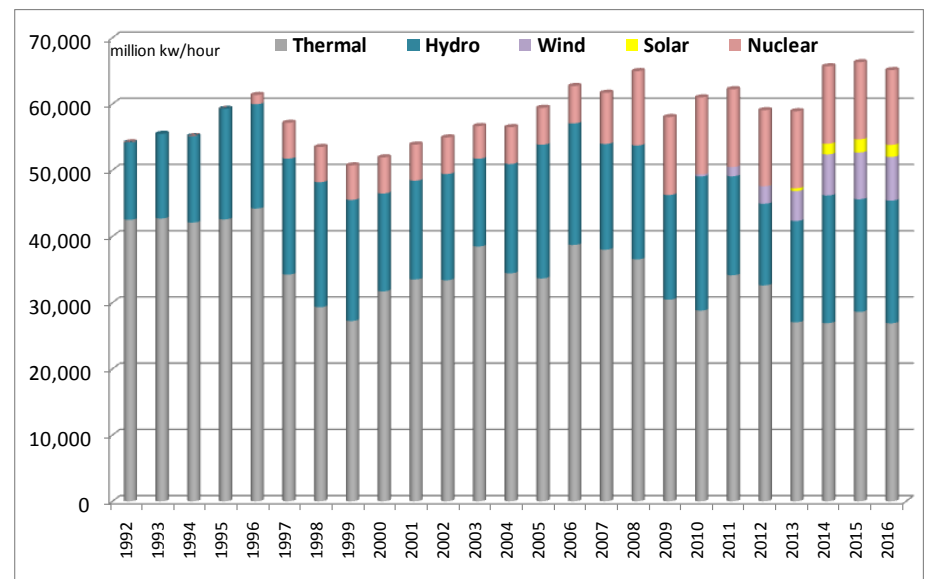

Fig. 2. Production of electric energy by type of energy plant (1996-2016).

Recently, wind and photovoltaic units have been massively developed in Romania. Although they have already made an important contribution to Romania's 2020 target of GHG emissions and decreased the import dependence, their intermittent nature has brought technical difficulties and integration costs into the National Power Grid (NPG). The wind farms have a greater installed power $(3,000 \mathrm{MW})$, relative to the photovoltaic 
(1,300 MW), considered to be the maximum for safe operation of NPG. However, the balancing market is less demanded by the power fluctuations of photovoltaic plants, producing more energy in summer and during the day, than by wind turbines generating more energy in winter and at night (Romanian Energy Strategy 2016-2030, 2016).

The environmental conditions of Romania enable a wide diversity of renewable sources with a significant energy potential (Fig. 3). The distribution of RES types depends on the physical-geographic features, especially relief and climate. Thus, the lowlands in southern and south-eastern Romania have significant solar, wind and biomass resources. Mountain areas have important biomass and micro-hydropower resources, while the western, southern and eastern parts of the country concentrate mostly geothermal, wind and solar resources.

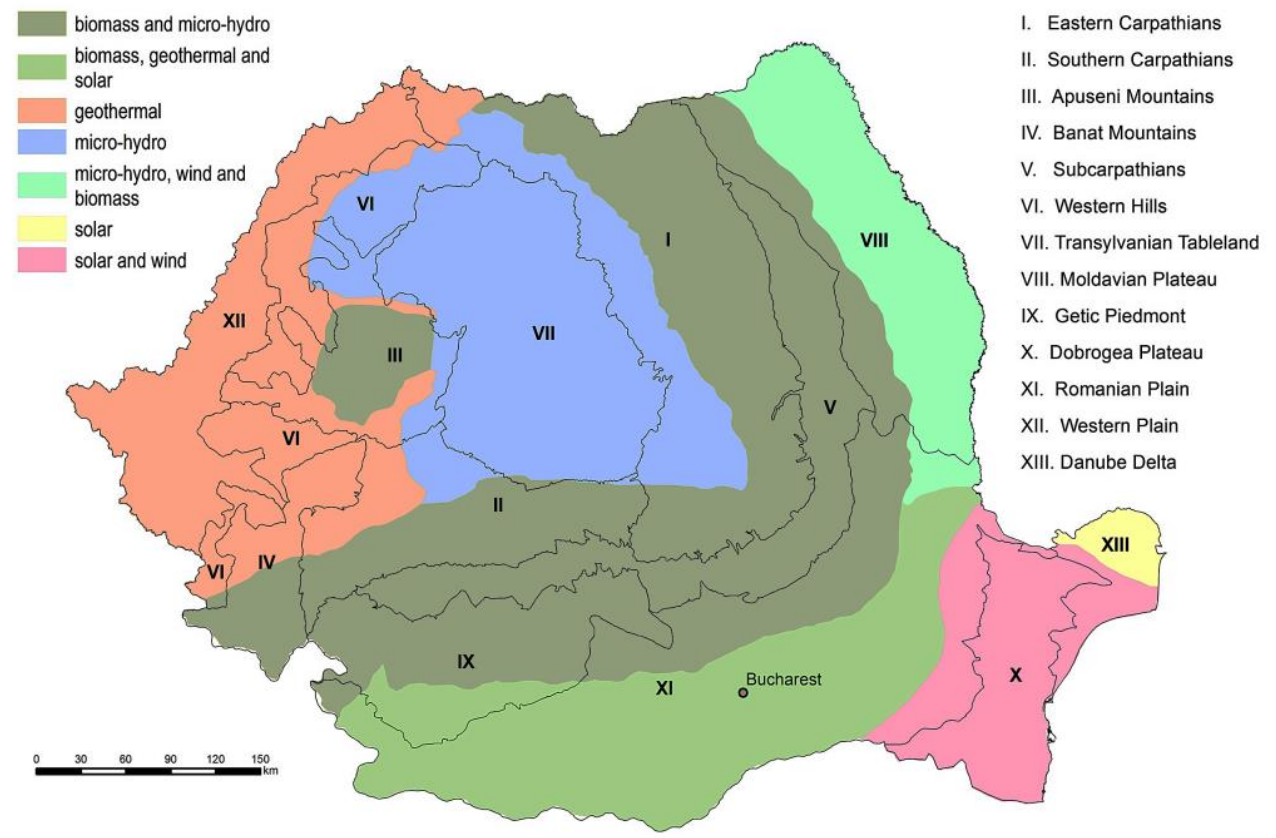

Fig. 3. Spatial distribution of RES types/potential on main relief units of Romania (processed and adapted after ANRE, 2016).

The structure of renewable energy mix depicts hydropower as the RES sector with the largest share (23\%) and its contribution could be maximized through future investments. The other RES sectors are wind (12\%), solar energy (2\%) and biomass (1\%) (http://version1.sistemulenergetic.ro/). RES in Romania are used mostly for electricity production (solar, wind, hydropower and biomass/biogas), for electricity and heating/cooling generation (solar and biomass/biogas) or only for heating (geothermal).

\subsection{Dynamics of RES electricity production and RES share in total electricity}

In the recent decade, electricity production from green energy sources showed a constant increase between 2013 and 2017, by 19.2\%. An outstanding production boost was 
recorded in solar energy by over $800 \%$, while the wind energy increased by $55.5 \%$. Although biomass has registered a significant overall increase between 2013 and 2017 (over 250\%), after 2016, it faced a slight decrease (Fig. 4). Although biomass is a climatefriendly resource, as compared to non-renewable energy, its use for household heating is still limited in Romania due to the associated environmental costs and short-lived climate pollutants (Romania. Climate Change and Low Carbon Green Growth Program, 2013). Relative to other EU countries, Romania holds the second position after Poland, by its renewable energy primary production (Cîrstea et al., 2018).

The share of RES in the electricity production in Romania registered a positive evolution, with a $3.1 \%$ year ${ }^{-1}$ between 2000 and 2016 and $7.8 \%$ year $^{-1}$ between 2015 and 2016, making possible the achievement of the EU target since 2015 (24.7\%). The greatest contribution to the target achievement was of the hydropower sector (one third of installed RES power generation capacity), followed by wind energy and biomass for heating (ANRE, 2016). This trend reveals the growing interest on improving the ecological performance and valorization of RES in the Romanian energy policy that could ensure an ascending evolution in the future if associated with effective measures for improving the performance-price balance in the implementation of RES technologies.

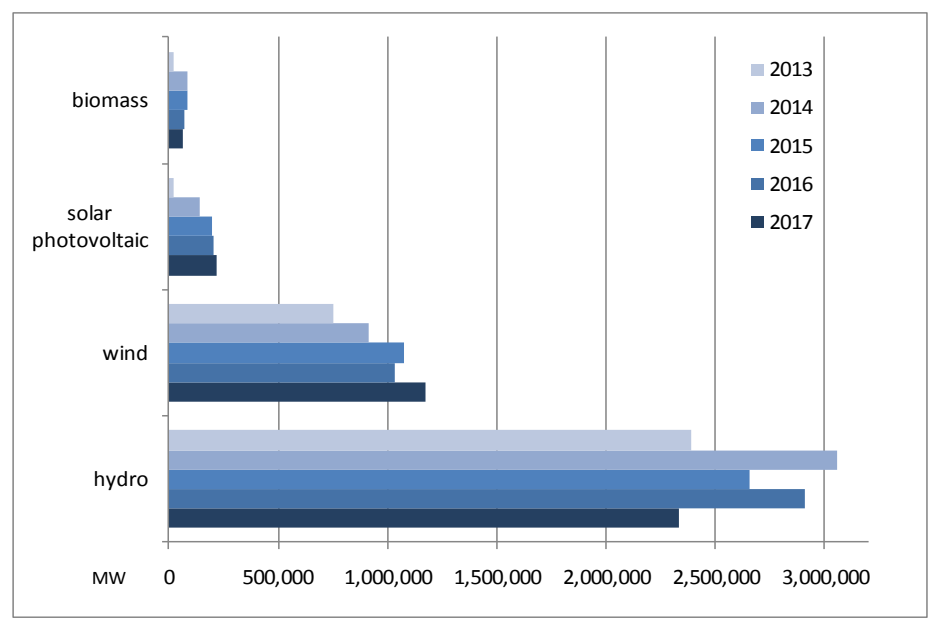

Fig. 4. Electricity production in Romania, by RES types.

The ratio between the non-renewable and the renewable energy shares (2013-2017) was fluctuating, largely depending on the local climatic conditions (e.g. influencing the performance of solar cells and wind farms), as well as on the provided support through national policies for renewable energy. Romania registered the highest shares of RES in the total electricity output in 2014 and 2016 (41.6\%, respectively 43.3\%) (Fig. 5).

It is worth mentioning that in 2016, Romania was among the nine EU member states (Croatia, Cyprus, Greece, Hungary, the Netherlands, Portugal, Slovakia and Sweden) which achieved their 2016 target by more than $10 \%$ (EEA, 2018). According to recent estimates, the gross final energy consumption from RES in Romania registered a significant positive change of $32 \%$ and an increase of RES share of about $7.7 \%$ in the 20052016 interval. The RES shares per sector (2016-2017) indicate that the greatest 
contribution is for electricity (RES-E) with about $43 \%$, followed by heating and cooling (RES-H/C) with about $27 \%$ and transport (RES-T) with only about 6\% (EEA, 2018).

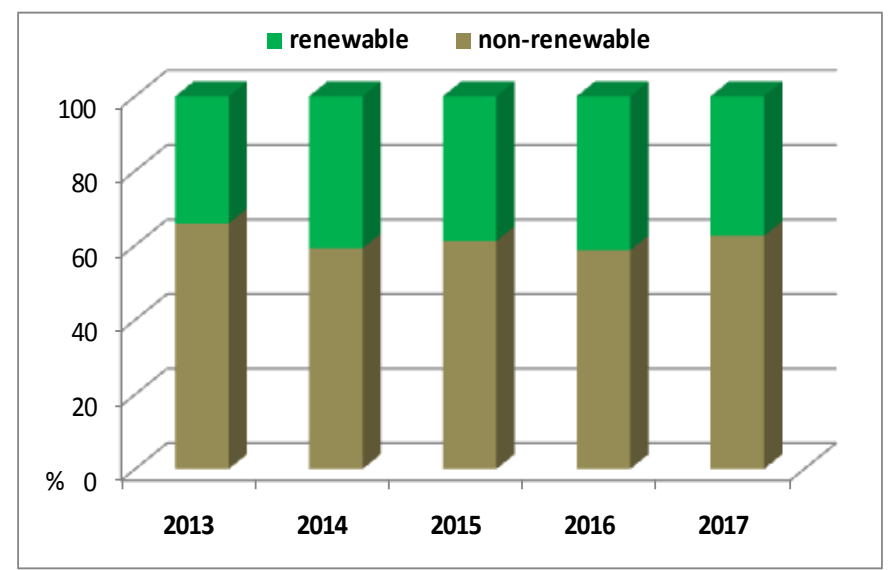

Fig. 5. Share of renewable/non-renewable energy production in Romania, 2013-2017.

\subsection{RES objectives in the EU and Romanian strategic documents (2007-2020)}

Currently, Romania has transposed all relevant EU Directives related to renewable energy into its regulatory framework. However, the recent economic and financial crisis (2008 - 2014) made the implementation of the European legislative provisions targeting the renewable energy sector difficult, especially since financial support schemes have been substantially reduced (or even ceased for the new installations producing electricity from RES, on December 31, 2016), subject to strict budgetary control. This situation determined a decrease in the number of issued Green Certificates.

In 2007, Romania has adopted its first Energy Strategy for 2007-2020 (issued on November 2007), which highlighted the main needs of the energy sector on medium and long-term: the decrease of electric and thermal energy consumption, the increase the energy efficiency by reducing the consumption of fossil fuels, the increase the number of jobs in green sectors, introduction and promotion of green technologies into industrial polluting sectors and the ongoing refinement of the competitive market mechanisms for achieving green and GHG emission certificates. Later, its revised version (Energy Strategy of Romania for 2016-2030, December 2016) complemented the previous one through measures for: promoting the development of the clean energy component (one of the key strategic goals), increasing the role of biomass in heating households, increasing energy efficiency of buildings and alleviating energy poverty (one of the main areas of state intervention), smart grids, energy storage and ghostly buildings, self-sustaining energy (one of the new directions of development). However, the strategy tackles no specific plans for a further support scheme for new RES installations. In response to the EU Directive 2009/28/EC, in 2010, Romania elaborated and submitted to the EU, the National Renewable Energy Action Plan (NREAP), which outlines how the increase in RES and energy efficiency and cuts in GHG emissions will be reached by 2020. The plan outlined the electricity targets from RES (of 33\% in 2010, 35\% in 2015 and 38\% in 2020), as well as the overall RES share target of $24 \%$ in the gross final energy consumption. In 2014, 
Romania adopted the Directive 2012/27/EU on energy efficiency (Law 121/2014) through supporting the security of energy supply, sustainable development and competitiveness, primary energy saving and GHG reducing (ANRE, 2016). An important step forward was also the elaboration of the National Climate Change Strategy 2013-2020 with two components aimed at reducing GHG emissions ("Mitigation") and reducing the effects of change climate ("Adaptation") (Grigorescu et al., 2016). However, Romania still has no National Energy and Climate Plan and this emerges as one of the three key energy policy priorities for 2019: protection of vulnerable consumers and mitigation of energy poverty based on competitive, energy markets and targeted social aid; energy efficiency; and promotion of digital energy (Dudău and Egenhofer, 2018).

The essential contribution of the energy sector to the country development, as well as to the increase of its economic competitiveness, life quality and the environment preservation, is underlined within the Partnership Agreement for Romania (2014-2020) (PA). PA covers five European Structural and Investment Funds (ESIF): the European Regional Development Fund (ERDF), the Cohesion Fund (CF), the European Social Fund (ESF), the European Agricultural Fund for Rural Development (EAFRD) and the European Maritime and Fisheries Fund (EMFF). According to the PA, ESIF is expected to support Romania's ability to achieve EU2020 objectives and national development priorities, including the transition towards a more energy efficient economy, especially under its Thematic Objective 4 (TO4 - Supporting the shift towards a low-carbon economy in all sectors). The estimated investments for the shift to a low carbon economy, including the further expansion of renewable energy ( $24 \%$ target), are about $€ 3.9$ billion. Another significant contribution to GHG reduction, increase of RES use and of energy efficiency is supported by PA under TO7 (Promoting sustainable transport and removing bottlenecks in key network infrastructures).

Romania's energy policy showed an increasing focus on renewable sources mainly in relation to the green energy commitments and EU targets and to the interest of investors. In March 2017, the Government approved the Emergency Ordinance No.24/2017, which comprised amendments to the country's main renewable energy Law no. 220/2008, providing some stability and transparency to the Green Certificate support scheme. In April 2017, a new state aid scheme has been approved by the Government Decision no. 216/2017 to promote energy production from less exploited energy sources (biomass, biogas and geothermal energy). However, relative to other RES countries, Romania has a limited attractiveness for renewable energy investments and deployment opportunities, as revealed by Renewable Energy Country Attractiveness Index (RECAI). In 2015, Romania was ranked the 35 th in the top 40 countries ( 44.5 score). In the following years, Romania faced a constant fall and currently is no longer considered attractive for investments in renewable energy (RECAI, 2017, 2018).

The current financial programming cycle of sectoral OPs provisioned mechanisms for promoting the shift to low-carbon economy and for the accomplishment of country's commitment to the EU's targets on GHG emissions reduction, RES quota, and energy efficiency, mainstreaming climate change adaptation and mitigation in the planning processes of all relevant sectors of the economy (e.g. energy, transport, agriculture, industry, waste management). The most relevant OPs which provide support through 
investment priorities for RES use are: Increase of Economic Competitiveness (ERDF), National Program for Rural Development (EAFRD), Large Infrastructure (ERDF, CF), Fisheries and Marine Affaires (EMFF). Other relevant strategic planning and multi-annual financial programming focusing on the mitigation of climate change effects and supporting the fulfillment of country's commitments on reducing GHG through setting as main subsidiary priorities the improvement of energy efficiency and the expanded use of RES, are: the National Development Plan (2007-2013), the National Sustainable Development Strategy 2013-2020-2030. Also, some significant opportunities for extending the RES use might arise from regional cooperation, promoting legal and administrative cooperation and public investments for sustainable cross-border infrastructure and transport under the Cooperation Programmes between Romania and its neighboring countries (e.g. Bulgaria, Hungary).

\section{CONCLUSIONS}

Guaranteeing the security and sustainability of energy are fundamental objectives of any energy strategy, which entails taking all political, economic and technical measures. Shifting to greener energy sources and technologies will significantly contribute to both the aforementioned objectives. At EU level, despite the high growth rates in the photovoltaic and wind sectors, bioenergy is the largest source of renewable energy providing heat, electricity and transport fuels and is expected maintain the same trend (Scarlat et al., 2015).

The economic efficiency of the use of energy from RES in Romania is still deficient due to a number of reasons such as: the high number of energy suppliers among those who maintain a high energy price; the implementation of a costly smart metering system aimed at supporting energy saving; the unequal ratio between the final production value; the malfunctioning of the green certificate support scheme etc. However, Romania has a significant RES potential that could ensure nation-wide benefits (GDP growth, improved quality of life), as well as a faster transition towards a low-carbon economy and a sustainable energy sector. Continuing and improving the existing RES-related policies and actions will provide opportunities to meet the next energy target (EU2030).

In view of the above, some actions should be envisaged: e.g. upholding the subsidizing policies through Green Certificates for the production of electricity from RES, mainly wind (Dragomir et al., 2016), integrating green solutions into urban areas (e.g. passive houses, electric vehicles), supporting green jobs in RES- related fields. The programming of the next cycle of sectoral OPs will need to integrate and mainstream climate-energy actions to support climate change mitigation and adaptation through an extended use of RES. An emergent need is also to implement actions for raising awareness on the nation-wide benefits of RES and to elaborate tailored regulatory and market-oriented measures, towards the achievement of the next ambitious RES target for 2030. 


\section{ACKNOWLEDGEMENTS}

This work was supported by the national project PN-III-P1-1.2-PCCDI-20170404/31PCCD/2018 (UEFISCDI) - Holistics of the renewable energy sources on environment and climate (HORESEC).

\section{REFERENCES}

1. ANRE (2016), Raport privind progresul înregistrat în îndeplinirea obiectivelor naţionale de eficienţă energetic (Report on the progress in meeting national energy efficiency targets in English). Departamentul de Eficienţă Energetică, 83 p. (https://www.anre.ro/ro/eficientaenergetica/rapoarte/rapoarte-de-progres).

2. Cî̀stea, Ş.D., Martiş, C.S., Cîrstea, A., Constantinescu-Dobra, A., Fülöp, M.T. (2018), Current situation and future perspectives of the Romanian renewable energy, Energies, 11, 3289.

3. Colesca, S.E., Ciocoiu, C.N. (2013). An overview of the Romanian renewable energy sector. Renewable and sustainable energy reviews, 24, 149-158.

4. Dragomir, G., Şerban, A., Năstase, G., Brezeanu, A.I. (2016), Wind energy in Romania: A review from 2009 to 2016, Renewable and Sustainable Energy Reviews, 64, 129-143.

5. Dudău, R., Egenhofer, C. (2018), Proposals for potential energy policy priorities during Romania's 2019 presidency of the Council of the European Union. Energy policy Group.

6. EEA (2018), Trends and projections in Europe 2018: Tracking progress towards Europe's climate and energy targets, EEA Report 116, $36 \mathrm{p}$.

7. EU Green Paper (2000), Towards a European strategy of energetic security, COM(2000) 769 final. Brussels.

8. EU Green Paper (2013), A 2030 framework for climate and energy policies, COM(2013) 169 final. Brussels.

9. Eurostat Report https://ec.europa.eu/eurostat/statisticsexplained/index.php/Renewable energy statistics

10. Europe 2020 Strategy, (2010), A strategy for smart, sustainable and inclusive growth European Commission http://eurlex.europa.eu/LexUriServ/LexUriServ.do?uri=COM:2010:2020:FIN:EN:PDF

11. Grigorescu, I., Kuscicsa, G., Sima, M., Dumitraşcu, M. (2016), Strategic approaches on Air Quality in Romania - 2035 Perspectives, Proceedings of the 16th International Multidisciplinary Scientific GeoConference SGEM, vol. II, 571-578, Albena, Bulgaria.

12. Radovanović, M., Filipović, S., Pavlović, D. (2017). Energy security measurement-A sustainable approach. Renewable and Sustainable Energy Reviews, 68, 1020-1032.

13. RECAI (2017), Issue 49: Batteries: leading the charge (http://www.ey.com).

14. RECAI (2018), Issue 52: index scores (http://www.ey.com)

15. Romania. Climate Change and Low Carbon Green Growth Program (2013). Component A1 Stocktaking Report, The International Bank of reconstruction and Development. $86 \mathrm{p}$.

16. Romanian Energy Strategy 2007 - 2020, updated for 2011 - 2020 (in Romanian), http://mmediu.ro/new/wp-content/uploads/2014/01/2011-1107 evaluare impact planuri_strategiaenergeticaactualizata2011.pdf

17. Romanian Energy Strategy 2016-2030, with an outlook to 2050 (in Romanian), http://www.mmediu.gov.ro/app/webroot/uploads/files/2017-03-02 Strategia-Energetica-a$\underline{\text { Romaniei-2016-2030.pdf }}$ 
18. Scarlat, N., Dallemand, J.F., Monforti-Ferrario, F., Banja, M., Motola, V. (2015), Renewable energy policy framework and bioenergy contribution in the European Union-An overview from National Renewable Energy Action Plans and Progress Reports. Renewable and Sustainable Energy Reviews, 51, 969-985.

19. Transelectrica (2018), http://version1.sistemulenergetic.ro/, Accessed November 2018

20. United Nations (2014), "Decade of Sustainable Energy for All 2014-2024", https://www.un.org/press/en/2012/ga11333.doc.htm

21. Zamfir, A., Colesca, S.E., Corbos, R.A. (2016), Public policies to support the development of renewable energy in Romania: A review. Renewable and Sustainable Energy Reviews, $58,87-106$.

22. http://statistici.insse.ro/shop/ (National Institute of Statistics: Tempo-Online).

23. http://version1.sistemulenergetic.ro/

24. http://ec.europa.eu/clima/policies/roadmap/index_en.htm (EU Commission Roadmap supporting the transition towards a low-carbon economy by 2050).

25.http://ec.europa.eu/energy/energy2020/roadmap/index_en.htm (Energy Roadmap 2050).

26. http://ec.europa.eu/transport/themes/strategies/2011_white_paper_en.htm (The Transport White Paper). 